\title{
Asymmetrical distribution of a mitochondrial DNA polymorphism between 2 introgressing honey bee subspecies
}

\author{
MD Meixner 1, WS Sheppard 2, J Poklukar 3 \\ 1 Institut für Bienenkunde (Polytechnische Gesellschaft), JW Goethe Universität, Frankfurt am Main, \\ Karl-von-Frisch-Weg 2, 6370 Oberursel, Germany; \\ 2 USDA-ARS, Bee Research Laboratory, BIdg 476, BARC-E, Beltsville, MD 20705, USA; \\ ${ }^{3}$ Agricultural Institute of Slovenia, Hacquetova 2, 61000 Ljubljana, Slovenia
}

(Received 2 February 1993; accepted 26 April 1993)

Summary - Mitochondrial DNA from 62 samples of Apis mellifera carnica and A m ligustica collected from within areas of endemism and an area of known introgression was extracted and digested with the restriction enzymes $A c c 1, B c h, B g \cap l, E c o R I$ and Xbal. Digestion with Xbal revealed a polymorphism with an asymmetrical distribution between the subspecies. This polymorphism occurs primarily in Austrian and Slovenian A $m$ carnica and may be useful for studying introgression between this race and $A m$ ligustica.

Apis mellifera / mitochondrial DNA / subspecies / population genetics

\section{INTRODUCTION}

A number of authors have used restriction site polymorphism within the mitochondrial DNA of Apis mellifera to investigate the population genetics of this insect (Hall and Muralidharan, 1989, Smith et al, 1989, 1991; Rinderer et al, 1991, Sheppard et al, 1991a,b; Moritz and Meusel 1992). Comparisons in these studies were based in part on restriction site variation that differentiates the mitochondria of African and European honey bee subspecies. Unfortunately, few such "diagnostic" restriction site polymorphisms are known to occur among most honey bee subspecies, although size polymorphism may be relatively common (Moritz et al, 1986; Smith 1988; Arias et al, 1990; Cornuet et al, 1991; Garnery et al, 1992). Restriction site polymorphisms have been reported within particular subspecies (Smith and Brown 1990), although sample size limitations prevent estimation of their frequency or distribution. 
In this paper we present evidence for the asymmetrical distribution of a mtDNA restriction site polymorphism between 2 honey bee subspecies, Apis mellifera carnica and $A m$ ligustica, from within their areas of endemism. The distribution of the polymorphism suggests that it occurs commonly in $A m$ carnica, and thus may be useful to study the introgression of this race with subspecies where the variant is in low frequency.

\section{MATERIAL AND METHODS}

Sixty-two colonies of honey bees ( $A \mathrm{~m}$ carnica and $A m$ ligustica and natural hybrids of both) were sampled from apiaries stocked with local bees in Austria (2 apiaries, 12 samples), Slovenia (5 apiaries, 30 samples) and Italy (Reggio Emilia, 1 apiary, 10 samples and Udine, 1 apiary, 10 samples) (fig 1). Whereas south-eastern Austria and Slovenia are areas with naturally- occurring $A m$ carnica and most of Italy contains endemic $A m$ ligustica, northeastern Italy (Udine) is an area of known hybridization between both races (Nazzi, 1992). Adult worker bees were taken from brood combs and stored in liquid nitrogen. Subspecies identification consisted of analysis of 15 workers per sample for 36 morphological characters using discriminant analysis procedures modified from Ruttner et al (1978).

Total nucleic extraction of 2 bees per colony was performed by a modified phenolic extraction method (Sheppard and McPheron, 1991). The nucleic acid extracts were stored at $-20^{\circ} \mathrm{C}$ in 10 $\mathrm{mM}$ Tris, $0.1 \mathrm{mM}$ EDTA. The DNA was digested with the following restriction endonucleases according to the manufacturer's instructions (Bethesda Research Laboratories, Bethesda, MD USA): $A c c, B c h, B g \wedge l, E c o R I$ and Xbal. The digests were electrophoresed in $1 \%$ agarose gels, stained with ethidium bromide and photographed with UV-illumination. Transfer to nitrocellulose filters was carried out according to the method of Southern (1975). The filters were prehybridized and hybridized at $50^{\circ} \mathrm{C}$ using stan-

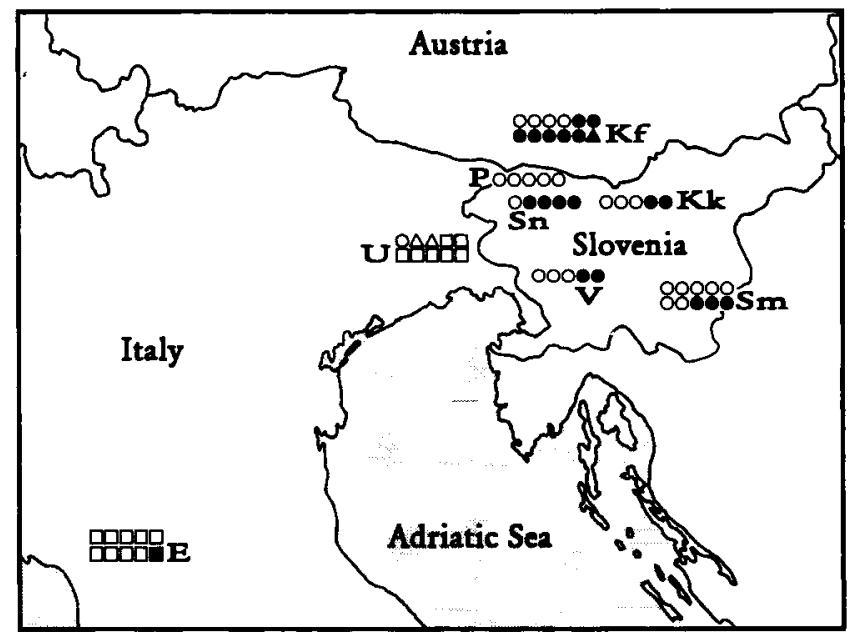

Fig 1. Morphological classification and Xbal restriction pattern distribution of sampled honey bee colonies. Each symbol represents one colony. Sampling locations are designated as follows: Austria: Klagenfurt (Kf) (2 apiaries); Slovenia: Podkoren (P), Senicno (Sn), Vhrnika (V), Kamnik (Kk) Semic (Sm) (2 apiaries); Italy: Udine (U) (Istituto Difesa delle Piante): Reggio Emilia (E) (Istituto Nazionale di Apicoitura). Symbols are assigned to the results of the morphometric analysis as follows: squares: $A \mathrm{~m} \mathrm{Ii-}$ gustica morphology; triangles: intermediate morphology; circles: A m carnica morphology. Open symbols indicate $X$ bal restriction pattern 1 , filled symbols indicate $X$ bal restriction pattern 2 (see text). 
dard solutions containing saimon sperm DNA and 25\% formamide (Maniatis et al, 1982; Sheppard et al, 1991b). Radioactive probe was produced through nick-translation of purified honey bee mitochondrial DNA (Sheppard et al, 1991b). Mitochondrial DNA restriction fragments were visualized by autoradiography.

\section{RESULTS AND DISCUSSION}

Discriminant analysis identified 42 of the colonies as $A$ m carnica and 16 as $A \mathrm{~m} \mathrm{li}$ gustica when compared to published subspecies morphometric data (Ruttner 1988) (fig 2). Within the carnica group there is a detectable subdivision into 2 morphotypes corresponding to "Alpine" and "Pannonic" types of A m carnica (Ruttner, 1988). Three colonies had intermediate discriminant scores and were considered as hybrids. The geographic distribution of the 2 subspecies and their hybrids corresponds to published data (Ruttner, 1988; Nazzi, 1992).
The fragment sizes and patterns of all samples obtained by digestion with Accl, $B c h, B g \| l$ and EcoRI correspond to the restriction maps published by Smith (1988) for $A m$ ligustica and $A m$ carnica and to those of Arias et al (1990) for $A$ m ligusti$c a$. For these enzymes, no variation was detected within or between the races.

Digestion with $X$ bal, however, produced 2 distinct restriction patterns differing by the presence of 1 cleavage site (fig 3 ). Pattern 2 consisted of four restriction fragments in our gels and appears to correspond to the Car2 pattern reported by Smith and Brown (1990) in their study of restriction site and length polymorphism in A $m$ carnica. Pattern 1 consisted of three restriction site fragments, and with the enzymes in our study could not be unambiguously assigned to their named restriction morphs. The restriction site responsible for the difference between the patterns appears to correspond to the Xbal site $q$ re-

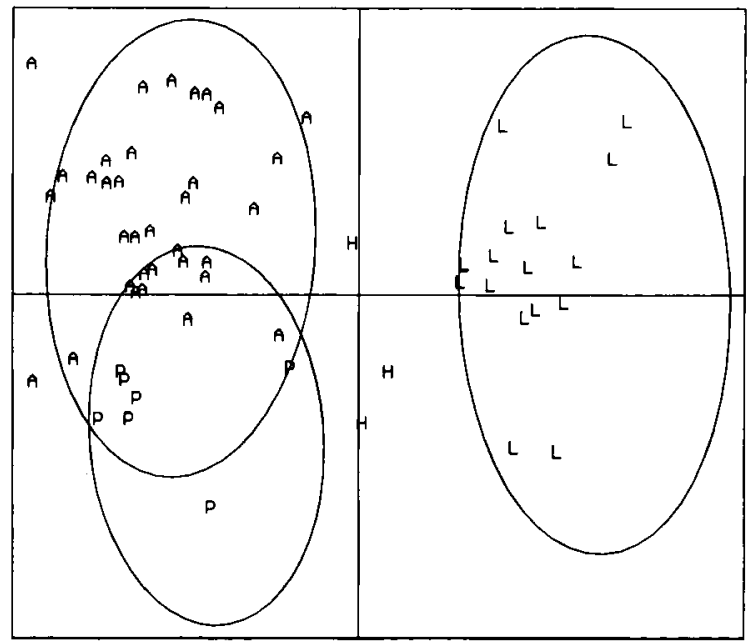

Fig 2. Positions of the samples investigated in a discriminant analysis. Abscissa: discriminant factor 1, ordinate: discriminant factor 2 . The confidence curves $(95 \%)$ are given. The discriminant factors and confidence curves were obtained from classified samples of honey bees from the Morphometric Data Collection in Oberursel. L: A m ligustica; A: A m carnica ("Alpine"); P: A m carnica ("Pannonic"); $\mathrm{H}$ : samples with intermediate discriminant scores, regarded as carnicalligustica hybrids. 
$\begin{array}{lllllllll}1 & 2 & 3 & 4 & 5 & 6 & 7 & 8 & 9\end{array}$

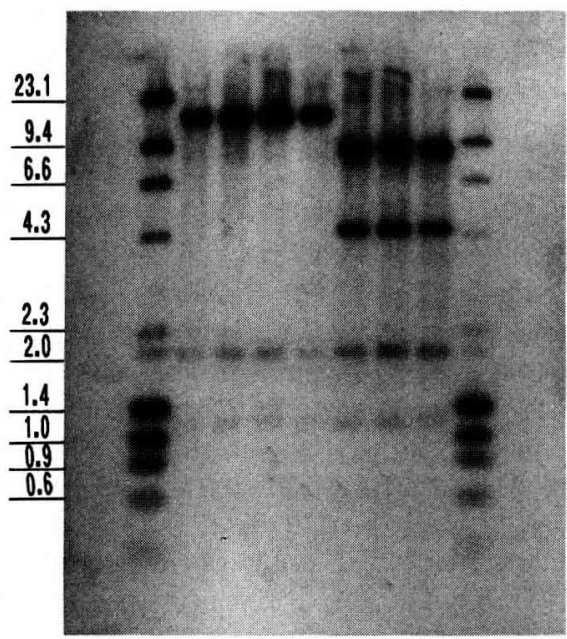

Fig 3. Autoradiograph of honey bee mitochondrial DNA showing the $2 X$ bal patterns observed in this study. Lanes 1 and 9: lambda DNA digested with HindllI and PhiX DNA digested with Haell. Xbal pattern 1: samples from Reggio Emilia ( $A$ m ligustica, lanes 2 and 5 ), Semic ( $A$ $m$ carnica, 3 ) and Kamnik ( $A$ m carnica, 4$)$, approximate fragment sizes estimated from the autoradiograph are 13.6, 1.95 and $1.3 \mathrm{~kb}$. Xbal pattern 2: A m carnica samples from Klagenfurt $(6,7)$ and Senicno $(8)$, approximate fragments sizes are $9.1,4.4,1.95$ and $1.3 \mathrm{~kb}$.

ported by Garnery et al (1992), with the presence of q producing pattern 2 .

Of the 62 colonies examined, 42 exhibited pattern 1 and 20 pattern 2 . In our samples, pattern 2 was predominantly limited to $A$ m carnica - 19 out of 42 colonies from Austria and Slovenia showed this pattern. The distribution of the patterns is shown in figure 1.

Although our samples represent a relatively small portion of the geographic ranges of the 2 subspecies and the area of hybridization between them, pattern 2 was common in samples with $A m$ carnica morphology and was found only once in $A \mathrm{~m} \mathrm{li}$ gustica and ligustica/carnica hybrids, respectively. Pattern 2 was widespread throughout the area of $A m$ carnica sampled with no indication of a clinal distribution, but additional samples covering the total range of $A$ m carnica would be needed to verify this. These results are in agreement with those of Garnery et al (1992), who found restriction site $q$ to be present in 4 out of $6 \mathrm{~A} \mathrm{~m}$ carnica colonies and absent from all $9 A \mathrm{~m}$ ligustica colonies they sampled. If additional analyses of endemic $A m$ ligustica and $A m$ carnica confirm an asymmetrical distribution of the patterns, then this polymorphism may be useful to study genetic introgression between these subspecies.

\section{ACKNOWLEDGMENTS}

We wish to thank M Milani, A Biasiolo and $N$ Lodesani for assistance in sampling bees in Italy. Bees from Austria were provided by beekeepers J Petscharnig and B Rainer. A Mohr assisted in morphometrical analysis of the samples. We thank F Ruttner, N Koeniger and MC Arias for discussion and comments on the manuscript. Part of this work was supported by the Fazit Foundation, Frankfurt, Germany.

Résumé - Distribution asymétrique du polymorphisme de I'ADN mitochondrial entre deux sous-especes d'abeilles domestiques (Apis mellifera $L$ ) introgressives. Soixante deux échantillons d'abeilles (Apis mellifera carnica, A $m$ ligustica et leurs hybrides naturels) ont été prélevés dans les régions où elles sont endémiques et dans une région d'introgression connue (fig 1). L'identification des sous-espèces a été faite à partir de 15 ouvrières par échantillon par des analyses discriminantes portant sur 36 caractères morphologi- 
ques. Après comparaison avec les données des sous-espèces publiées par Ruttner (1988) (fig 2), 42 colonies ont été classées comme carnica et 16 comme ligustica. Trois colonies ont obtenu une note discriminante intermédiaire et ont été considérées comme hybrides. Une extraction totale des acides nucléiques de 2 abeilles par échantillon a été réalisée (Sheppard et McPheron, 1991) et l'ADN a été digéré par les endonucléases de restriction $A c c$ I, $B c /$ I, Bgl II, EcoR I et Xba I. Après électrophorèse sur gels d'agarose à $1 \%$, I'ADN a été transféré sur une membrane de nitrocellulose et hybridé à $50^{\circ} \mathrm{C}$ à l'aide de solutions standard contenant 25\% de formamide (Maniatis et al, 1982; Sheppard et al, 1991b). La sonde utilisée a été de l'ADNmt purifié d'abeille marqué radioactivement par translation d'entaille. Les fragments de restriction de l'ADNm ont été visualisés par autoradiographie.

Alors que la digestion par $A c c \mathrm{l}, B c / \mathrm{l}$, $B g /$ II et $E c o R$ I n'a pas révélé de variation dans nos échantillons, la digestion par $X b a$ I a produit 2 profils distincts se différenciant par la présence d'un seul site de clivage (fig 3). Le profil 2 était constitué de 4 fragments et semble correspondre au profil Car2 signalé par Smith et Brown (1990), tandis que le profil 1 , constitué de 3 fragments, n'a pas pu être assigné de façon sûre à l'un des morphes de restriction. Le site de clivage responsable de la différence entre les 2 profils semble correspondre au site q signalé par Garnery et al (1992). Sur les 62 échantillons examinés, 42 ont présenté le profil 1 et 20 le profil 2. Le profil 2 est limité de manière prédominante à A m carnica - 19 des 42 colonies provenant d'Autriche et de Slovénie présentent ce profil (fig 1). Bien que nos échantillons ne représentent qu'une partie relativement restreinte de l'aire de répartition des 2 sous-espèces, le profil 2 est courant dans les échantillons qui présentent une mor- phologie de type carnica et rare dans les ligustica et les hybrides, mais il ne donne pas signe d'une distribution clinale. Si les analyses complémentaires d'abeilles carnica et ligustica endémiques confirment la distribution asymétrique des profils, il pourrait être utile d'utiliser ce polymorphisme pour étudier l'introgression génétique entre ces sous-espèces.

Apis mellifera / sous-espèce / ADN mitochondrial / génétique des populations

Zusammenfassung - Asymmetrische Verteilung eines Polymorphismus der mitochondrialen DNA in zwei benachbarten geographischer Rassen der Honigbienen. 62 Proben von Honigbienen (Apis mellifera carnica, $A m$ ligustica und natürliche Hybriden) wurden in Italien, Österreich und Slowenien gesammelt (Abb1).

Jeweils 15 Bienen eines Volkes wurden anhand von 36 Merkmalen nach Ruttner et al (1978) morphologisch klassifiziert. Eine Diskriminanzanalyse identifizierte 42 der Proben als $A m$ carnica und 16 als $A m$ igustica (Abb 2). Drei Proben hatten intermediäre Diskrimanzwerte und wurden als Hybriden betrachtet.

Die DNA von jeweils 2 Bienen pro Probe wurde nach der Methode von Sheppard und McPheron (1991) extrahiert und mit den Restriktionsendonukleasen $A c c$ I, $B c l$ I, Bgl II, EcoR I und Xba I abgebaut. Nach Elektrophorese in 1\% Agarosegelen wurden die Fragmente auf Nitrocellulosefilter transferiert (Southern, 1975) und bei $50{ }^{\circ} \mathrm{C}$ unter Standardbedingungen hybridisiert (Maniatis et al, 1982; Sheppard et al, 1991b). Die radioaktive Sonde wurde durch Nick-Translation gereinigter mtDNA von Honigbienen hergestellt (Sheppard et al, 1991b). Die mitochondrialen Restriktionsfragmente wurden durch Autoradiographie sichtbar gemacht. 
Während die durch den Abbau der mtDNA mit $A c c$ I, Bcll, Bgl II und EcoR I hergestellten Fragmentmuster in allen untersuchten Proben keine Variation zeigten, entstanden durch den Abbau mit Xba I zwei deutlich verschiedene Muster, die sich in einer Schnittstelle unterscheiden (Abb 3). Unser Muster 2 bestand aus 4 Fragmenten und scheint dem von Smith und Brown (1990) veröffentlichten Car2 Muster zu entsprechen, während Muster 1 keinem ihrer Fragmentmuster widerspruchsfrei zugeordnet werden konnte.

Die für den Unterschied zwischen den Fragmentmustern verantwortliche Schnittstelle scheint der von Garnery et al (1992) gefundenen Schnittstelle q zu entsprechen.

Von den 62 untersuchten Proben, zeigten 42 Muster 1 und 20 Muster 2. Muster 2 ist weitgehend auf $A m$ carnica beschränkt - es ist in 19 von den 42 in Österreich und Slowenien gesammelten Proben vorhanden (Abb1). Obwohl unsere Sammlung nur einen geringen Anteil der Verbreitungsgebiete beider Unterarten repräsentiert, war Muster 2 in Proben mit $A$ m carnica Morphologie verbreitet und wurde in $A$ $m$ ligustica sowie Hybriden jeweils nur einmal gefunderı. Aus den Proben unserer Sammlung ergibt sich jedoch kein Hinweis auf eine klinale Verbreitung. Wenn sich die asymmetrische Verteilung dieser Fragmentmuster durch weitere Analysen von endemischer $A$ m carnica und ligustica bestätigen läßt, könnte dieser Polymorphismus zur Untersuchung der genetischen Introgression zwischen diesen beiden Subspezies genutzt werden.

\section{Apis mellifera / mtDNA / Unterart / Ge- netik der Populationen}

\section{REFERENCES}

Arias MC, Soares AEE, Nobrega FG (1990) Improvements to the mitochondrial restriction maps for Italian and Africanized honey bees. Braz J Genet 13, 501-507

Cornuet JM, Garnery L, Solignac M (1991) Putative origin and function of the intergenic region between $\mathrm{COI}$ and $\mathrm{COII}$ of Apis mellifera L mitochondrial DNA. Genetics 128, 393-403

Garnery L, Cornuet JM, Solignac M (1992) Evolutionary history of the honey bee Apis mellifera inferred from mitochondrial DNA analysis. Mol Ecol 1, 145-154

Hall HG, Muralidharan K (1989) Evidence from mitochondrial DNA that African honey bees spread as continuous maternal lineage. $\mathrm{Na}$ ture 339, 211-213

Maniatis T, Frisch EF, Sambrook J (1982) Molecular Cloning. Cold Spring Harbor, NY, 545 $\mathrm{pp}$

Moritz RFA, Meusel MS (1992) Mitochondrial gene frequencies in Africanized honeybees (Apis mellifera $L$ ): theoretical model and empirical evidence. J Evol Biol 5, 71-82

Moritz RFA, Hawkins CF, Crozier RH, Mackinley AG (1986) A mitochondrial DNA polymorphism in honeybees (Apis mellifera L). Experientia $42,322-324$

Nazzi F (1992) Morphometric analysis of honey bees from an area of racial hybridization in northeastern italy. Apidologie 23, 89-96

Rinderer TE, Stelzer JA, Oldroyd B, Buco SM, Rubink WL (1991) Hybridization between European and Africanized honey bees in the neotropical Yucatan peninsula. Science 253, 309-311

Ruttner F (1988) Biogeography and Taxonomy of honeybees. Springer, Heidelberg

Ruttner F, Tassencourt L, Louveaux J (1978) Biometrical-statistical analysis of the geographic variability of Apis mellifera L. 1. Material and methods. Apidologie 9, 363-381

Sheppard WS, McPheron BA (1991) Ribosomal DNA diversity in Apis. In: Diversity in Apis (Smith DR, ed) Westview Press, Boulder, $\mathrm{CO}, 89-102$

Sheppard WS, Rinderer TE, Mazzoli JA, Stelzer JA, Shimanuki H (1991a) Gene flow between African- and European-derived honey bee populations in Argentina. Nature 349, 782 784

Sheppard WS, Soares AEE, DeJong D, Shimanuki $H$ (1991b) Hybrid status of honey bee 
populations near the origin of Africanization in Brazil. Apidologie 22, 643-652

Smith DR (1988) Mitochondrial DNA polymorphisms in five Old World subspecies of honey bees and in New World hybrids. In: Africanized Honey Bees and Bee Mites (Needham R, Page RE, Delfinado-Baker M, Bowman CE, eds) Ellis Horwood, Chichester, 303-312

Smith DR, Brown WM (1990) Restriction endonuclease cleavage site and length polymorphisms in mitochondrial DNA of Apis mellifera mellifera and $A m$ carnica (Hymenoptera: Apidae). Ann Entomol Soc Am 83, 81-88
Smith DR, Taylor OR, Brown WM (1989) Neotropical Africanized honeybees have African mitochondrial DNA. Nature 339, 213215

Smith DR, Palopoli MF, Taylor BR, Garnery L, Cornuet JM, Solignac M, Brown WM (1991) Geographical overlap of two mitochondrial genomes in Spanish honeybees (Apis mellifera iberica). J Hered 82, 96-100

Southern EM (1975) Detection of specific sequences among DNA fragments separated by gel electrophoresis. J Mol Biol 98, 503517 